\title{
The Effect of General and Spinal Anaesthesia on Pulmonary Function Tests in Geriatric Patients
}

\section{Geriatrik Hastalarda Genel ve Spinal Anestezinin Solunum Fonksiyon Testleri Üzerine Etkisi}

\author{
(1) Vildan Kölükçü̈1, (1) Tuğba Karaman², (1) Serkan Karaman², (1) Serkan Doğru2², (1) Hakan Tapar², (1) Mustafa Süren² \\ ${ }^{1}$ Tokat Zile State Hospital, Clinic of Anesthesiology and Reanimation, Tokat, Turkey \\ ${ }^{2}$ Tokat Gaziosmanpaşa University Faculty of Medicine, Department of Anesthesiology and Reanimation, Tokat, Turkey
}

\begin{abstract}
Introduction: This study aimed to compare the effects of general and spinal anaesthesia on pulmonary function tests (PFT) in the postoperative period among patients aged $\geq 65$ years.

Methods: This prospective study included a total of 60 patients aged $\geq 65$ years with American Society of Anesthesiologists I-III. General anaesthesia was applied to group I while spinal anaesthesia was applied to group II. PFTs were performed in all the patients in the preoperative evaluation and were repeated at the $2^{\text {nd }}$ and $24^{\text {th }}$ postoperative hours. Comparison of the results was done both within and between the groups.

Results: A comparison between the groups showed that both in the preoperative and postoperative periods, forced expiratory volume in the first second (FEV1), forced vital capacity (FVC), the ratio of FEV1 to FVC (FEV1/FVC, Tiffeneau ratio), forced expiratory flow between $25 \%$ and $75 \%$ of the FVC (FEF2575), peak expiratory flow and forced expiratory time values were not statistically significant $(p>0.05)$. However, when the patients were compared within the groups, a statistically significant decrease in FEV1 and FVC values was found in the postoperative spirometric measurements in both groups compared to the preoperative period $(p<0.05)$.
\end{abstract}

Conclusion: General or spinal anaesthesia adversely affects PFTs in elderly patients.

Keywords: Elderly, general anaesthesia, spinal anaesthesia, pulmonary function tests

\section{öZ}

Amaç: Genel ve spinal anestezinin postoperatif dönemde 65 yaș ve üstü hastalarda solunum fonksiyon testleri (SFT) üzerine etkisinin incelenmesi amaçlanmıştır.

Yöntemler: Bu ileriye dönük çalıșmada Amerikan Anesteziyoloji Derneği I ile III aralığında 65 yaş ve üstü toplam 60 hasta değerlendirilmiştir. Genel anestezi uygulanan hastalar grup I, spinal anestezi uygulananlar ise grup II olarak sınıflanlandırılmıştır. Tüm olgulara ameliyat öncesi ve ameliyat sonrası 2. ve 24. saatlerde SFT yapılmıștır. SFT sonuçları gruplar arasında analiz edilmiștir.

Bulgular: Birinci saniye zorlu ekspiratuvar volüm (FEV1), zorlu vital kapasite (FVC), birinci saniye zorlu ekspiratuvar volümün (FEV1'in FVC'ye) zorlu vital kapasiteye oranı (FEV1/FVC, Tiffeneau oranı) zorlu ekspirasyon ortası akım hızı (FEF25-75), tepe akım hızı, zorlu ekspiryum zamanı değerlerinde gruplar arasında istatistiksel olarak anlamlı farklılık saptanmadı ( $p>0,05)$. Bununla birlikte genel anestezi ve spinal anestezi uygulanan hastalar grup içi değerlendirildiğinde her iki grupta da FEV1 ve FVC değerlerinde preoperatif döneme göre postoperatif spirometrik ölçümlerde istatistiksel olarak anlamlı bir azalma gözlendi $(p<0,05)$.

Sonuç: Yașlı hastalarda genel veya spinal anestezi SFT'lerini benzer şekilde olumsuz etkilemektedir.

Anahtar Kelimeler: Yașlı, genel anestezi, spinal anestezi, solunum fonksiyon testleri

\section{Introduction}

Ageing is a physiological process affected by multiple factors such as lifestyle, environment, genetics, social environment, work environment and chronic diseases. It involves changes in physiological functions that occur over time without any particular disease. According to the World Health Organization, people aged $\geq 65$ years are defined as "old" while people aged $\geq 80$ years as "late elderly". Life expectancy in our country has been extended similar to that of the rest of the world. The elderly population is increasing along with related diseases that increase with ageing and require surgery. Accordingly, surgery and anaesthesia applications in elderly patients are becoming increasingly frequent $(1,2)$.

With ageing, major changes are observed in all systems. One of the most obvious changes occurs in the respiratory system. The risk of
Address for Correspondence/Yazıșma Adresi: Vildan Kölükçü MD, Tokat Zile State Hospital, Clinic of Anesthesiology and Reanimation, Tokat, Turkey

Phone: +90 5064313312 E-mail: vildankolukcu@gmail.com 0RCID ID: orcid.org/0000-0002-3914-3899

Cite this article as/Atıf: Kölükçü V, Karaman T, Karaman S, Doğru S, Tapar H, Süren M. The Effect of General and Spinal Anaesthesia on Pulmonary Function Tests in Geriatric Patients. İstanbul Med J 2020; 21(6): 462-467.
Received/Geliș Tarihi: 16.07.2020 Accepted/Kabul Tarihi: 10.10 .2020

(C) Copyright 2020 by the University of Health Sciences Turkey, Istanbul Training and Research Hospital/istanbul Medical Journal published by Galenos Publishing House.

(C) Telif Hakkı 2020 Sağlık Bilimleri Üniversitesi Istanbul Ĕgitim ve Araştırma Hastanesi/Istanbul Tıp Dergisi, Galenos Yayınevi tarafından basılmıștır. 
perioperative pulmonary complications increases due to changes in the lung structure, lung mechanics and pulmonary blood flow in the elderly (3). Therefore, pulmonary function tests (PFT) can be an important assessment tool for predicting postoperative pulmonary complications. They provide more objective data than medical history and physical examination in demonstrating the presence and severity of respiratory dysfunction in patients to undergo surgery (4). In addition to the changing physiology, the anaesthesia techniques to be used are highly important in elderly patients with planned surgery. The effects of different anaesthesia methods on the respiratory function of elderly patients vary and their superiority to each other is controversial (5-7).

To our knowledge, there is a limited number of publications in the literature that compare the effects of general anaesthesia and spinal anaesthesia on PFTs $(8,9)$. Therefore, this study aimed to compare the effects of general and spinal anaesthesia on PFTs in elderly patients with planned extremity surgery.

\section{Methods}

The study was approved by the Ethics Committee of Gaziosmanpaşa University, Gaziosmanpaşa (13-KAEK-236) and was registered as a clinical trial at ClinicalTrials.gov (http://www.clinicaltrials.gov) with the identification number NCT03399201 (decision no: 83116987-036, date: 27.01.2014). In addition, informed consent was obtained from each patient. The study included 60 patients aged $\geq 65$ years with American Society of Anesthesiology (ASA) scores I-III, and who were to undergo general or spinal anaesthesia in the Research and Application Center of the Faculty of Medicine at Gaziosmanpaşa University between February and December 2018.

Patients with contraindications for spinal anaesthesia, those with known respiratory diseases or obesity (body mass index $>30 \mathrm{~kg} / \mathrm{m}^{2}$ ) or those whose surgery was in a position other than the supine position were excluded. Patients randomised using the closed envelope technique were divided into two groups: Group I (general anaesthesia) $(n=30)$ and group II (spinal anaesthesia) ( $n=30)$. In all patients, venous vascular access was performed from the back of the hand or the antecubital fossa with a 20 gauge $(\mathrm{G})$ branule in the operation room. Electrocardiogram (ECG), peripheral oxygen saturation and non-invasive blood pressure monitoring were performed using a bedside monitor (GE Datex-Ohmeda F-CM1-05 Anesthesia Monitor, Helsinki, Finland). Patients in group I were preoxygenated through spontaneous breathing, with the mask containing $100 \% \mathrm{O}_{2}$ and fresh gas flow at $5 \mathrm{~L} / \mathrm{min}$ for three minutes. Induction was performed with $1-2 \mathrm{mcg} / \mathrm{kg}$ fentanyl and $5-7 \mathrm{mg} / \mathrm{kg}$ thiopental. After achieving muscle relaxation with $0.6 \mathrm{mg} / \mathrm{kg}$ rocuronium, the patients were intubated with an appropriate diameter endotracheal tube. In the maintenance anaesthesia, 1 minimum alveolar concentration sevoflurane and $50 \% \mathrm{O}_{2}$-air mixture was used. The mode of mechanical ventilation in the anaesthesia machine (GE-Datex-Ohmeda S/5 Avance, USA) was the "synchronized intermittent mandatory ventilation mode" with a tidal volume of $7-10 \mathrm{~mL} / \mathrm{kg}$, breathing frequency of $12 / \mathrm{min}, \mathrm{I}$ : $\mathrm{E}$ ratio of $1: 2$ and positive end-expiratory pressure of $4-5 \mathrm{~cm} \mathrm{H}_{2} \mathrm{O}$. At the end of the surgery, the patients were extubated with neostigmine at 0.03 $\mathrm{mg} / \mathrm{kg} \mathrm{IV}$ and atropine at $0.01 \mathrm{mg} / \mathrm{kg}$ IV to restore the neuromuscular blockage. In group II, $12.5 \mathrm{mg}$ ( $2.5 \mathrm{~mL}$ ) of $0.5 \%$ hyperbaric bupivacaine was applied in the sitting position using a $25 \mathrm{G}$ atraumatic spinal needle (Egemen ${ }^{\circledR}$ spinal needle, Egemen International, Turkey) from the L3-4 or L4-5 range, with a midline spinal puncture. After the spinal anaesthesia, the sensory block level was determined by a pin-prick test. The loss of stinging/pain sensation to a needle tip was evaluated down the middle clavicular line. The T6-8 levels were the sufficient sensory block levels for the surgery. The surgery was started when the block reached these levels. The patients were given $3 \mathrm{~L} / \mathrm{min}$ oxygen by nasal cannula during the surgery.

In the preoperative evaluation, all the patients were explained how the PFT was performed and the same practitioner performed the tests when the patients' numerical pain score was three and below. PFTs were performed in the sitting position using a portable spirometry device (Spirodoc class IIA/Roma Italy) before the surgery, and at the postoperative $2^{\text {nd }}$ and $24^{\text {th }}$ hours. Forced expiratory volume in the first second (FEV1), forced vital capacity (FVC), the ratio of FEV1 to FVC (FEV1/ FVC, Tiffeneau ratio), forced expiratory flow between $25 \%$ and $75 \%$ of the FVC (FEF25-75), peak expiratory flow (PEF) and forced expiratory time (FET) values were recorded as well as the demographic information and duration of the surgery.

\section{Statistical Analysis}

All the data were evaluated using the software Statistical Package for Social Sciences 20.0 (SPSS Inc. Chicago, IL). P $<0.05$ was accepted as statistically significant. The Kolmogorov-Smirnov test was used to evaluate the compliance of the data to a normal distribution. Descriptive data are presented as mean (standard deviation) for normally distributed data and as median for non-normally distribution data. The distance between quarters is presented as $25^{\text {th }}$ and $75^{\text {th }}$ percentiles, and categorical data are presented as number (frequency). The categorical data were compared using Pearson's chi-square test or Fisher's Exact chi-square test. The independent t-test was used to compare the groups when the continuous data was normally distributed, and the MannWhitney $U$ test was used to compare the groups when the continuous data was not normally distributed. Analysis of variance was used to compare repeated measurements. Bonferroni-corrected multiple comparisons were used to determine the different groups. Friedman's test was used for repeated measurements that did not fit the normal distribution. Dunn's test with Bonferroni correction was applied to determine different groups. It was used as a multiple comparison test.

\section{Results}

There was no statistically significant difference between the groups in terms of demographic data, sex, duration of operation, smoking and ASA score (Table 1) ( $p>0.05)$. FEV1, FVC, FEV1/FVC, FEF25-75 and PEF values were compared among the patients included in the study. There was no significant difference in the preoperative period, at the postoperative $2^{\text {nd }}$ hour and $24^{\text {th }}$ hour in the intergroup evaluation (Table 2) $(p>0.05)$. According to the comparison within the groups, the FEV1 value decreased significantly in both groups over time. There was a significant difference in FEV1 at the basal-postoperative $2^{\text {nd }}$ hour $(p=0.002)$ and $24^{\text {th }}$ hour $(p=0.004)$ in group I; in FEV1 at the basal-postoperative $24^{\text {th }}$ hour $(p=0.001)$ in group II (Figure 1$)$. We found a statistically significant 
decrease in FVC over time in both groups. The difference in FVC was as follows: with regard to the basal-postoperative $2^{\text {nd }}$ hour $(p=0.035)$ and $24^{\text {th }}$ hour $(p=0.011)$ values in group $I$, and the basal-postoperative $2^{\text {nd }}$ hour $(p=0.007)$ and $24^{\text {th }}$ hour $(p=0.001)$ values in group II (Figure 2$)$.

\section{Discussion}

Due to developments in the field of health and advances in social life, the number and proportion of the elderly in the total population are steadily increasing. Depending on the increase in the elderly population and the diseases requiring surgery with ageing, it is predicted that surgery and anaesthesia applications will be more frequent in the future. The respiratory system among other systems experiences the most changes with ageing (10). A study evaluating the effect of ageing on pulmonary function parameters demonstrated a progressive decrease in PFT parameters with ageing in patients $>60$ years (11). Studies to determine spirometric reference values in the elderly have associated the following with a decrease in spirometric values: in addition to known respiratory system diseases, the use of cardiac glycoside, beta-blockers, diuretics, theophylline and diabetic drugs; smoking for more than five packs per year; conditions such as exertional dyspnoea, hypertension,

Table 1. Demographic data and operation times

\begin{tabular}{|c|c|c|c|}
\hline & Group I $(n=30)$ & Group II $(n=30)$ & $\mathbf{p}^{*}$ \\
\hline Age (years) median (lower limit - upper limit) & $70(65-82)$ & $67.5(65-93)$ & $0.32^{\mathrm{a}}$ \\
\hline $\operatorname{Sex}(M / F) n$ & $10 / 20$ & $11 / 19$ & $0.79^{\mathrm{b}}$ \\
\hline Weight $(\mathrm{kg})$ mean \pm SD & $78.4 \pm 14.78$ & $78.10 \pm 12.23$ & $0.93^{c}$ \\
\hline Operation duration (min) median (lower limit - upper limit) & $145(75-250)$ & $126(90-225)$ & $0.096^{a}$ \\
\hline
\end{tabular}

Table 2. Preoperative and postoperative pulmonary function test measurements

\begin{tabular}{|c|c|c|c|}
\hline & Group I $(n=30)$ & Group II $(n=30)$ & p \\
\hline \multicolumn{4}{|l|}{ FEV1 } \\
\hline Preoperative median (lower limit-upper limit) & $1.86(1.12-3.33)$ & $1.91(1.12-2.91)$ & $0.78^{\mathrm{a}}$ \\
\hline $2^{\text {nd }}$ hour median (lower limit-upper limit) & $1.58(0.93-3.14)$ & $1.67(0.83-3.24)$ & $0.37^{\mathrm{a}}$ \\
\hline $24^{\text {th }}$ hour median (lower limit-upper limit) & $1.54(1.14-3.35)$ & $1.61(0.90-3.00)$ & $0.81^{a}$ \\
\hline \multicolumn{4}{|l|}{ FVC } \\
\hline Preoperative median (lower limit-upper limit) & $2.39(1.12-4.62)$ & $2.45(1.12-3.58)$ & $0.80^{\mathrm{a}}$ \\
\hline $2^{\text {nd }}$ hour median (lower limit-upper limit) & $1.97(0.93-3.88)$ & $2.28(1.10-3.60)$ & $0.68^{\mathrm{a}}$ \\
\hline $24^{\text {nd }}$ hour median (lower limit-upper limit) & $1.93(1.21-4.15)$ & $2.06(1.24-3.35)$ & $0.24^{\mathrm{a}}$ \\
\hline \multicolumn{4}{|l|}{ FEF25-75 } \\
\hline Preoperative median (lower limit-upper limit) & $1.79(1.00-3.83)$ & $1.98(1.01-5.09)$ & $0.64^{\mathrm{a}}$ \\
\hline $2^{\text {nd }}$ hour median (lower limit-upper limit) & $1.85(0.76-3.33)$ & $2.01(0.72-4.75)$ & $0.35^{\mathrm{a}}$ \\
\hline $24^{\text {th }}$ hour median (lower limit-upper limit) & $1.95(1.04-3.51)$ & $1.85(0.59-4.58)$ & $0.68^{a}$ \\
\hline \multicolumn{4}{|l|}{ PEF } \\
\hline Preoperative median (lower limit-upper limit) & $3.68(1.94-6.91)$ & $3.66(1.34-8.77)$ & $0.85^{\mathrm{a}}$ \\
\hline $2^{\text {nd }}$ hour median (lower limit-upper limit) & $3.33(1.82-6.97)$ & $3.69(1.87-9.84)$ & $0.12^{\mathrm{a}}$ \\
\hline $24^{\text {th }}$ hour median (lower limit-upper limit) & $3.51(1.67-7.21)$ & $3.51(1.45-9.84)$ & $0.61^{\mathrm{a}}$ \\
\hline \multicolumn{4}{|l|}{ FET } \\
\hline Preoperative median (lower limit-upper limit) & $4.07(0.93-6.52)$ & $3.84(0.63-6.28)$ & $0.93^{\mathrm{a}}$ \\
\hline $2^{\text {nd }}$ hour median (lower limit-upper limit) & $3.12(0.86-6.50)$ & $3.43(1.27-9.71)$ & $0.24^{a}$ \\
\hline $24^{\text {th }}$ hour median (lower limit-upper limit) & $3.38(0.95-6.12)$ & $3.92(2.06-7.01)$ & $0.29^{\mathrm{a}}$ \\
\hline \multicolumn{4}{|l|}{ FEV1/FVC } \\
\hline Preoperative median (lower limit-upper limit) & $0.78(0.54-1.00)$ & $0.81(0.51-1.00)$ & $0.45^{\mathrm{a}}$ \\
\hline $2^{\text {nd }}$ hour median (lower limit-upper limit) & $0.79(0.57-1.00)$ & $0.82(0.58-1.05)$ & $0.13^{\mathrm{a}}$ \\
\hline $24^{\text {th }}$ hour median (lower limit-upper limit) & $0.82(0.59-1.44)$ & $0.80(0.51-0.90)$ & $0.30^{\mathrm{a}}$ \\
\hline
\end{tabular}


major ECG anomalies, previous history of thoracic surgery and evidence of pretibial oedema $(12,13)$. In our study, preoperative FEV1 and FVC values were lower compared to those of studies conducted to determine spirometric reference values in the elderly. Our study excluded cases with primary lung disease. However, $90 \%$ of our study population had accompanying conditions that are known to result in a decrease in PFTs such as hypertension, diabetes and beta-blocker use. This may have contributed to the lower PFT values. With advanced age, smoking, immobilisation and the supine position cause the closing capacity to be higher than the functional residual capacity (FRC), which results in atelectasis (8). Our study group included orthopaedic patients who were elderly and with limited mobilisation. This may have caused spirometric measurements to be low due to a possible underlying atelectasis.

Anaesthesia methods used during surgery have their advantages and disadvantages when compared with each other. General anaesthesia reduces regional ventilation by lowering the FRC. As the FRC approaches the closing capacity, small airways collapse, atelectasis occurs and perioperative atelectasis worsens underlying chronic lung diseases $(14,15)$. Several studies in the literature have shown a statistically

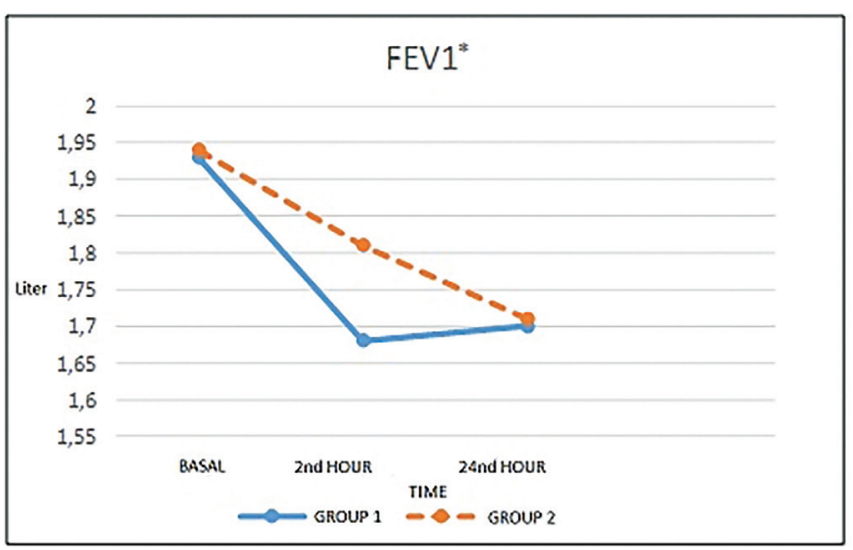

Figure 1. Comparison of volume in the first second mean values within and between the groups

FEV1: Volume in the first second

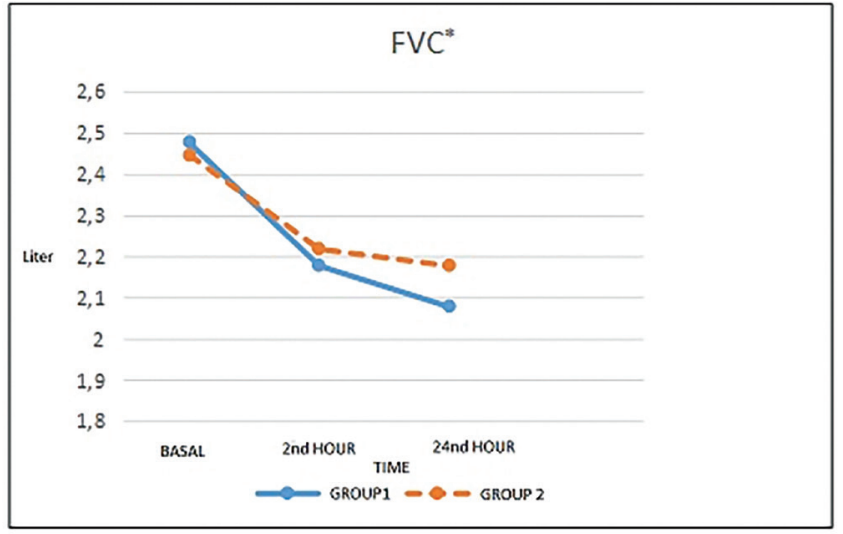

Figure 2. Comparison of forced vital capacity mean values within and between the groups

FVC: Forced vital capacity significant decrease in the postoperative spirometric values of patients who underwent general anaesthesia compared to the preoperative period (16-19). Similarly, we observed a statistically significant decrease in FEV1 and FVC values in the postoperative period compared to the preoperative period in group I patients, while no significant difference was found in FEV1/FVC, FEF25-75, PEF and FET values. It is compatible with the spirometric restriction that the FEV1/FVC ratio is normal while FEV1 and FVC are low. This measurement occurs in cases of true restriction, mixed obstruction-restriction or non-specific ventilation pattern, and the diagnosis is made through a detailed evaluation (20). The result of our spirometric measurements suggests that the development of atelectasis due to general anaesthesia in our cases highlights a restrictive type postoperative respiratory dysfunction and requires detailed evaluation.

Spinal anaesthesia can also have negative effects on pulmonary function parameters. Studies evaluating the respiratory functions before and after the intervention in surgeries with spinal anaesthesia found a statistically significant decrease in spirometric values in the postoperative period compared to the preoperative period (21-23). Oğurlu et al. (1) evaluated 50 patients to examine the effects of spinal anaesthesia on PFTs. They reported a statistically significant decrease in basal FVC, FEV1 and FEF2575 values in patients (in the 60-85 age group) with spinal anaesthesia above the thoracic $6^{\text {th }}$ (T6) level in the postoperative $40^{\text {th }}$ minute compared to the preoperative period. However, the mean FVC, FEV1 and FEF25-75 values were lower in the $40^{\text {th }}$ minute postoperatively compared to the preoperative period in patients with a spinal anaesthesia level below the T6 level, albeit not significant. Similar to the literature data, our study found a statistically significant decrease in the postoperative FEV1 and FVC values of group II patients compared to the preoperative period (1,21-23). In the same group, there was no statistically significant difference in the mean FEF25-75, PEF, FET values and FEV1/FVC ratio at the $2^{\text {nd }}$ and $24^{\text {th }}$ postoperative hours compared to the preoperative period. In spinal anaesthesia, the level of the motor block above the T6 level affects the accessory expiratory muscles, causing a decrease in vital capacity and FVC. The lack of ventilation caused by this situation and the supine position may lead to atelectasis (8). We think that a restrictive type of respiratory dysfunction occurred after spinal anaesthesia, similar to that in group $\mathrm{I}$.

There is a very limited number of publications in the literature that compares the effects of regional and general anaesthesia on pulmonary functions. Ungern-Sternberg et al. (8) recorded the basal spirometric values of patients by examining the effects of general and spinal anaesthesia on perioperative spirometric values in 84 patients aged between 22-84 years, with a planned gynaecological surgery. Then, by applying the preferred anaesthesia technique, they repeated the spirometric measurement at the $20^{\text {th }}$ minute, $1^{\text {st }}$ hour, $2^{\text {nd }}$ hour and $3^{\text {rd }}$ hour postoperatively. A statistically significant decrease was recorded in all values after premedication compared to the basal values in both groups. There was also a decrease in all postoperative values, and this decrease was statistically significant in the general anaesthesia group compared to the spinal anaesthesia group. Another study examined 100 cases between 39-47 years of age to compare the effects of spinal and general anaesthesia on pulmonary functions. PFTs showed a statistically 
significant decrease in the general anaesthesia group in the postoperative period compared to those who received spinal anaesthesia. In addition, when the preoperative and postoperative values were compared, there was a statistically significant decrease in the postoperative values in both anaesthesia groups compared to the preoperative period (9). In our study, the spirometric values of both groups were significantly decreased in terms of the FEV1 and FVC in the postoperative period compared to the preoperative period. However, we did not find a statistically significant difference between group I and group II. Since the preoperative spirometric values of our patients were lower than the reference values, we may not be able to show the difference between the groups that may occur in the postoperative period compared to the preoperative period. In addition, the decrease in both groups in the postoperative period compared to the preoperative period may be due to the increase in the closing capacity that occurs with ageing, and the decrease in the FRC due to the supine position and anaesthesia effect, both contributing to the development of atelectasis.

The limitations of our study were as follows: The number of cases was small. The condition of the lungs before and after the surgery could not be evaluated by computed tomography, chest radiography or ultrasound. The absence of a lung disease was based only on a verbal declaration. Preoperative spirometric values were lower than the reference values.

\section{Conclusion}

We found that the preoperative PFTs of elderly patients with planned extremity surgery are quite low compared to those reported in the literature. Both anaesthesia methods led to a similar decrease in PFTs. Although new studies are needed to confirm the results, we think that a preoperative examination of the respiratory system, a good evaluation of respiratory functions and lung capacity may be much more beneficial compared to the choice of the anaesthesia technique in the anaesthesia management of elderly patients.

\section{Ethics}

Ethics Committee Approval: The study was approved by the Ethics Committee of Gaziosmanpaşa University, Gaziosmanpaşa (13-KAEK-236) and was registered as a clinical trial at ClinicalTrials.gov (http://www. clinicaltrials.gov) with the identification number NCT03399201 (decision no: 83116987-036 date: 27.01.2014).

Informed Consent: Informed consent was obtained from each patient.

Peer-review: Externally peer-reviewed.

Authorship Contributions: Surgical and Medical Practices - V.K., T.K., S.K., S.D., H.T., M.S.; Concept - V.K., T.K., S.K., S.D.; Design - V.K., T.K., S.K., S.D., H.T., M.S.; Data Collection or Processing - V.K., T.K., S.K., S.D., H.T., M.S.; Analysis or Interpretation - V.K., T.K., S.K., H.T.; Literature Search V.K., T.K., M.S.; Writing -. V.K., T.K., S.K.

Conflict of Interest: No conflict of interest was declared by the authors.

Financial Disclosure: The authors declared that this study received no financial support.

\section{References}

1. Oğurlu M, Sen S, Polatli M, Sirthan E, Gürsoy F, Cildağ O. The effect of spinal anesthesia on pulmonary function tests in old patients. Tuberk Toraks 2007; 55: 64-70.

2. Tosato M, Zamboni V, Ferrini A, Cesari M. The aging process and potential interventions to extend life expectancy. Clin Interv Aging 2007; 2: 401-12.

3. Alvis BD, Hughes CG. Physiology Considerationsin Geriatric Patients. Anesthesiol Clin 2015; 33: 447-56.

4. Kocabas A, Kara K, Ozgur G, Sonmez H, Burgut R. Value of preoperative spirometry to predict postoperative pulmonary complications. Respir Med 1996; 90: 25-33.

5. O'Hara DA, Duff A, Berlin JA, Poses RM, Lawrence VA, Huber EC, et al. The effect of anesthetic technique on postoperative outcomes in hip fracture repair. Anesthesiology 2000; 92: 947-57.

6. Gilbert TB, Hawkes WG, Hebel JR, Hudson JI, Kenzora JE, Zimmerman SI, et al. Spinal anesthesia versus general anesthesia for hip fracture repair: a longitudinal observation of 741 elderly patients during 2-year follow-up. Am J Orthop (Belle Mead NJ) 2000; 29: 25-35.

7. Şahin SH, Heybeli N, Çolak A, Arar C, Alan K, Çopuroğlu C, et al. Comparison of different anesthetic techniques on postoperative outcomes in elderly patients with hip fracture. Turkiye Klinikleri J Med Sci 2012; 32: 623-9.

8. Ungern-Sternberg BS, Regli A, Reber A, Schneider MC. Comparison of perioperative spirometric data following spinal or general anaesthesia in normal-weight and overweight gynaecological patients. Acta Anaesthesiol Scand 2005; 49: 940-8.

9. Al-Janabi MM. Effect of Spinal Versus General Anesthesia on Pulmonary Functions among Adults at Al-Sadder Medical City: Comparative Study. Kufa Journal For Nursing Sciences 2016; 6: 134-41.

10. Kimmick G, Muss HB. Breast cancer in older patients. Semin Oncol 2004; 31: 234-48.

11. Dhar R, Gupta M, Khajuria V, Singh N. Evaluation of pulmonary function tests in elderly population. Int J Med Sci Public Health 2016; 6: 1-5.

12. Enright PL, Kronmal RA, Higgins M, Schenker M, Haponik EF. Spirometry reference values for women and men 65 to 85 years of age. Cardiovascular health study. Am Rev Respir Dis 1993; 147: 125-33.

13. McDonnell WF, Enright PL, Abbey DE, Knutsen SF, Peters JA, Burchette RJ, et al. Spirometric reference equations for older adults. Respir Med 1998; 92: 914 21.

14. Saraswat V. Effects of anaesthesia techniques and drugs on pulmonary function. Indian J Anaesth 2015; 59: 557-64.

15. Hong CM, Galvagno Jr SM. Patients with chronic pulmonary disease. Med Clin North Am 2013; 97: 1095-107.

16. Tiefenthaler W, Pehboeck D, Hammerle E, Kavakebi P, Benzer A. Lung function after total intravenous anaesthesia or balanced anaesthesia with sevoflurane Br J Anaesth 2011; 106: 272-6.

17. Doger C, Kahveci K, Ornek D, But A, Aksoy M, Gokcinar D, et al. Effects of LowFlow Sevoflurane Anesthesia on Pulmonary Functions in Patients Undergoing Laparoscopic Abdominal Surgery. Biomed Res Int 2016; 2016: 3068467.

18. Karayiannakis AJ, Makri GG, Mantzioka A, Karousos D, Karatzas G. Postoperative pulmonary function after laparoscopic and open cholecystectomy. $\mathrm{Br} J$ Anaesth 1996; 77: 448-52.

19. Kim YS, Lim BG, Kim H, Kong MH, Lee IO. Effects of propofol or desflurane on post-operative spirometry in elderly after knee surgery: a double-blind randomised study. Acta Anaesthesiol Scand 2015; 59: 788-95.

20. Ruppel GL, Enright PL. Pulmonary Function Testing: Conference Summary Resp Care 2012; 57: 165-75. 
21. Șen S, Uğur B, Polatlı M, Yüksel H, Oğurlu M, Gezer E. The Effects of Spinal Anesthesia on Pulmonary Function Tests in Pregnant Women Undergoing Ceserean Section. Turk Thorac J 2007; 8: 69-72.

22. YIlmaz C, Buyrukcu SO, Cansever T, Gulsen S, Altinors N, Caner H. Lumbar microdiscectomy with spinal anesthesia: comparison of prone and kneechest positions in means of hemodynamic and respiratory function. Spine (Phila Pa 1976) 2010; 35: 1176-84.
23. Regli A, von Ungern-Sternberg BS, Reber A, Schneider MC. Impact of spinal anaesthesia on peri-operative lung volumes in obese and morbidly obese female patients. Anaesthesia 2006; 61: 215-21. 